\title{
Broadening the scope of Baeyer-Villiger monooxygenase activities toward $\alpha, \beta$-unsaturated ketones: a promising route to chiral enol-lactones and ene-lactones $\dagger$
}

Cite this: Chem. Commun., 2014, 50, 7793

Received 7th April 2014, Accepted 12th May 2014

DOI: $10.1039 /$ c4cc02541e

www.rsc.org/chemcomm

\author{
T. Reignier,$\ddagger^{a}$ V. de Berardinis, $\ddagger^{b}$ J.-L. Petit, ${ }^{b}$ A. Mariage, ${ }^{b}$ K. Hamzé, ${ }^{a}$ K. Duquesne ${ }^{a}$ \\ and V. Alphand*a
}

\begin{abstract}
Three regiodivergent Baeyer-Villiger mono-oxygenases (enantioselectively) oxidized a series of cyclic $\alpha, \beta$-unsaturated ketones into (chiral) either enol-lactones or ene-lactones. An easy-to-use and efficient biocatalytic process based on a host-microorganism deprived of unwanted activities (knock-out mutant) was developed to enable the exclusive synthesis of unsaturated lactones.
\end{abstract}

Conjugated ene-lactones ${ }^{1}$ and enol-lactones ${ }^{2}$ are frequently used as motifs in diverse bioactive synthetic and natural products. They are also valuable intermediates in organic synthesis ${ }^{3}$ and offer a promising route to the synthesis of other motifs widely found in nature such as dihydrooxepines. ${ }^{4}$ Nevertheless, the synthesis of such lactones, especially in the context of medium size rings, is not straightforward. ${ }^{5,6}$ The classical ring-closing approaches such as lactonization $^{1 f, 2 d}$ and ring-closing metathesis ${ }^{7}$ can be inefficient due to kinetic or thermodynamic limitations. ${ }^{5}$ The most direct route, the Baeyer-Villiger (BV) oxidation of $\alpha, \beta$-unsaturated ketones, when performed chemically always produces racemic enol-lactone and suffers from frequent side-reactions. ${ }^{8}$ Regarding enzymatic BV oxidation it is commonly thought that enones are not oxidized by Baeyer-Villiger monooxygenases (BVMOs) even though these enzymes display both regioselectivity and high stereospecificity toward a large range of saturated ketones. ${ }^{9}$

BVMOs are a highly versatile class of flavoenzymes able to perform the efficient catalysis of chemo-, regio- and enantioselective oxygenation reactions. ${ }^{9}$ Classically, an atom from dioxygen is incorporated to transform ketones into esters or lactones while consuming NADPH, a cofactor required as an electron donor. The reactive species, C4a-peroxyflavin, ${ }^{10}$ acts as a nucleophile to give a Criegeelike intermediate that undergoes the same type of rearrangement as

\footnotetext{
${ }^{a}$ Aix Marseille Université, Centrale Marseille, CNRS iSm2 UMR 7313, 13397 Marseille, France. E-mail: v.alphand@univ-amu.fr; Fax: +33491288440 ${ }^{b}$ CEA, Institut de Genomique, Genoscope, Université Evry Val d'Essonne (UEVE), CNRS, UMR Génomique métabolique, 2 rue Gaston Crémieux, 91057 Evry, France $\dagger$ Electronic supplementary information (ESI) available: Enzyme sequences, genomic constructions experimental procedures and product characterization data. See DOI: $10.1039 / \mathrm{c} 4 \mathrm{cc} 02541 \mathrm{e}$

\$ These authors contributed equally to this work.
}

in chemical BV reactions. Besides BV oxidation of ketones, the enzymes are able to oxygenate sulfur, selenium, nitrogen, boron atoms and, much more exceptionally, epoxidize the double bond. The main difference when compared to chemical reagents comes from the general lack of activity against $\alpha, \beta$-unsaturated ketones. ${ }^{9,11}$ To the best of our knowledge, the only unambiguous mention of such a reaction being enzymatically catalyzed was reported in 1996: the oxidation of 5-hexyl-2-cyclopenten-1-one by pure cyclopentanone monooxygenase from Comamonas sp. NCIMB $9872\left(\mathrm{CPMO}_{\mathrm{Coma}}\right)^{12}$ Since no other publications have described BVMO-mediated enol or ene-lactone formation, ${ }^{13}$ thus syntheses of these compounds remain challenging. ${ }^{5,6 a}$

We confirmed here that (asymmetric) enzymatic BV oxidation of cyclic enones is possible and offers a promising route for the synthesis of (chiral) unsaturated lactones. We report for the first time the BV oxidation of a series of $\alpha, \beta$-unsaturated ketones using $\mathrm{CPMO}_{\mathrm{Coma}}$ and two new BVMOs. The enzymes displayed a complementary regioselectivity and enantioselectivity, leading to either the corresponding conjugated ene-lactones or enol-lactones. An easy-to-use and efficient biocatalytic process based on a host-microorganism deprived of unwanted endogenous reductase activity was also developed.

$\mathrm{BVMO}_{\text {Ocean }}$, from Oceanicola batsensis DSM 15984, and BVMO ${ }_{\text {Parvi, }}$ from Parvibaculum lavamentivorans DSM 13023, were selected in the course of screening of sixty putative bacterial Type I BVMOs chosen from genomic databases to cover the genomic diversity as well as possible. ${ }^{14}$ The genes were heterologously expressed in $E$. coli strain BL21(DE3). ${ }^{15}$ The activities of the corresponding enzymes were assayed against various ketone substrates by monitoring NADPH depletion in crude extracts. Only two extracts displayed activity against

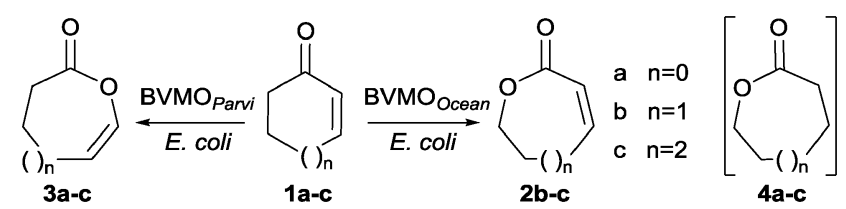

Scheme 1 Biotransformations using $\mathrm{BVMO}_{\text {Ocean }}$ and $\mathrm{BVMO}_{\text {Parvi }}$ expressed in E. coli BL21(DE3) strains. 
Table 1 Biotransformations of unsubstituted cycloalkenones $1 \mathrm{1a}-\mathrm{c}$ by non-deleted and deleted E. coli BL21(DE3) strains producing BVMOs

\begin{tabular}{|c|c|c|c|c|c|}
\hline Enzyme $^{a, b}$ & 1 & $\begin{array}{l}\text { Residual } 1 \\
\text { yield }^{c}(\%)\end{array}$ & $\begin{array}{l}2 \text { yield }^{c} \\
(\%)\end{array}$ & $\begin{array}{l}3 \text { yield }^{c} \\
(\%)\end{array}$ & $\begin{array}{l}4 \text { yield }^{c} \\
(\%)\end{array}$ \\
\hline \multirow[t]{3}{*}{$\mathrm{BVMO}_{\text {Ocean }}$} & $1 \mathrm{a}$ & $70(81)$ & - & - & $8(0)$ \\
\hline & $1 b$ & - & $39(79)$ & - & $43(5)$ \\
\hline & $1 \mathrm{c}$ & - & $83(80)$ & - & $8(0)$ \\
\hline \multirow[t]{3}{*}{ BVMO $_{\text {Parvi }}$} & 1a & - & - & $81(85)$ & $1(0)$ \\
\hline & $1 b$ & - & - & $60(74)$ & $11(<1)$ \\
\hline & $1 \mathrm{c}$ & $15^{d}(40)$ & - & 10 (19) & $3(0)$ \\
\hline
\end{tabular}

${ }^{a}$ Values corresponding to the experiments carried out with engineered E. coli BL21(DE3) strains are shown in parentheses. ${ }^{b}$ Biotransformations were carried out at the $3 \mathrm{mM}$ scale in $2 \mathrm{~L}$ flasks. ${ }^{c}$ Yields were determined by GC analysis using decane or undecane as internal standard. ${ }^{d} 50 \%$ of cycloheptanone was concurrently formed from $1 \mathrm{c}$ reduction.

cycloalkenones 1a-c (Scheme 1), these results were confirmed by experiments on the purified enzymes (see ESI $\dagger$ ).

Whole-cell biotransformations ${ }^{16}$ of $1 \mathbf{1 a}-\mathbf{c}$ were carried out for product identification. Unsaturated lactones were formed with both strains as reported in Table 1 . In the experiments with $E$. coli

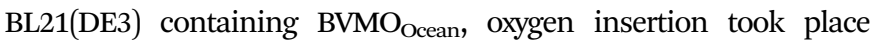
between the carbonyl group and the non-ethylenic carbon atom to give conjugated ene-lactones $\mathbf{2 b}$ and $\mathbf{2 c}$ while lactone $\mathbf{2 a}$ formation was not observed. The regioselectivity was similar to that previously reported with $\mathrm{CPMO}_{\text {Coma }}$ on 5-hexyl-2-cyclopentenone ${ }^{12}$ and opposite to that described in the classical chemical BV reaction. ${ }^{8}$

Enol-lactones 3a-c were exclusively produced with $E$. coli

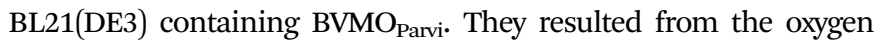
atom insertion between the carbonyl group and the double bond as observed in chemical BV oxidation. However the epoxidation of the double bond, a frequent side-reaction that has prevented chemical $\mathrm{BV}$ oxidation being used for the synthesis of ene-lactones $3 \mathbf{a}-\mathbf{c},{ }^{4,8}$ was not observed.

Construction of an engineered strain deprived of ene-reductase activity: large amounts of saturated ketones or corresponding saturated lactones were formed with both strains (Table 1), lessening the interest in these microbiological transformations. The presence of cycloalkenone reductase activity in E. coli BL21(DE3) was confirmed by whole-cell biotransformation of 1a-c (see ESI $\dagger$ ) while unsaturated lactones were not hydrogenated. The reductase required nicotinamide cofactors, with a preference for NADPH as type I BVMOs. The literature ${ }^{11,17}$ suggested that NemA reductase is a good candidate and its contribution to cycloalkenone hydrogenation was confirmed when we tested the knock-out mutant BW25113 4 nemA obtained from the Keio collection. ${ }^{18}$ An E. coli BL21(DE3) expression strain without active enone reductase was engineered by exchanging nem $\mathrm{A}$ gene for $\Delta$ nem $\mathrm{A}$ knockout cassette from BW25113 $\Delta$ nemA using bacteriophage P1 transduction. ${ }^{19}$ The newly engineered BL21(DE3) $\Delta$ nemA strain was then used as a host for the overexpression of $\mathrm{BVMO}_{\text {Ocean }}$ and $\mathrm{BVMO}_{\text {Parvi }}$.

Preparative biotransformations using newly constructed strains: biotransformations carried out with the new biocatalysts, BL21(DE3)AnemA strains expressing BVMO Ocean $_{\text {and BVMO }}$ Parvi, showed the almost complete abolition of the saturated lactone formation (Table 1). These experiments clearly demonstrated

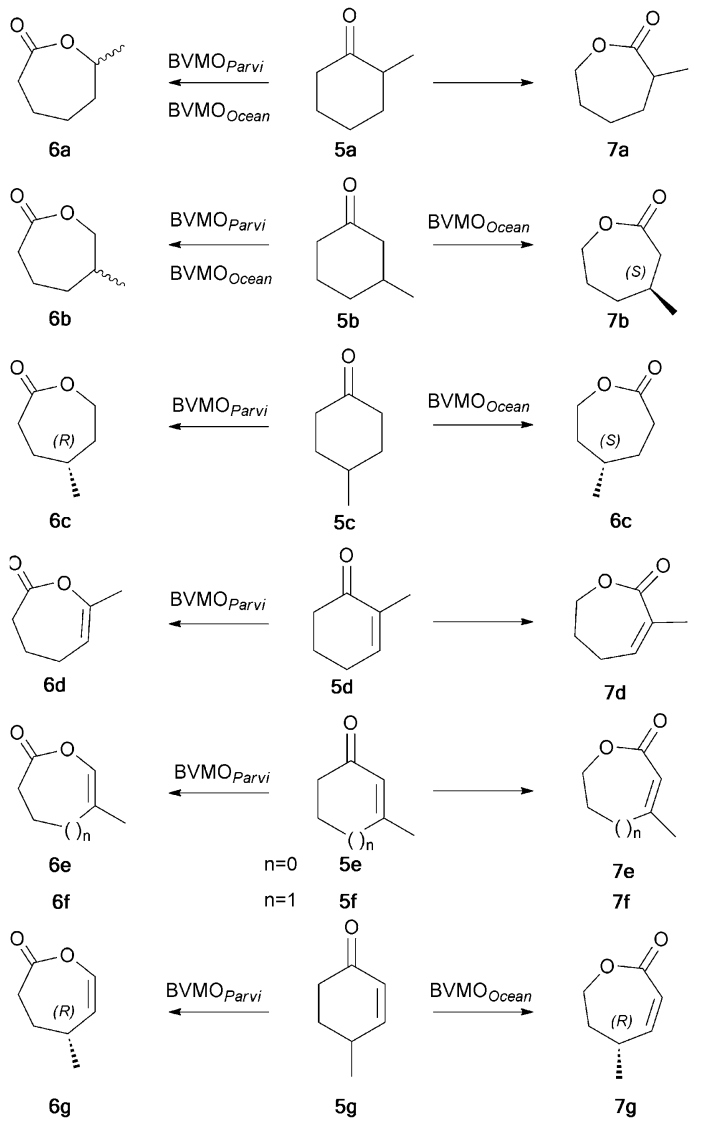

Scheme 2 Biotransformation of methylated cycloalkanones and cycloalkenones by $\mathrm{BVMO}_{\mathrm{O} \text { cean }}$ and $\mathrm{BVMO}_{\text {Parvi }}$ expressed in knock-out $E$. coli strains.

that the knock-out strains producing BVMOs were suitable for large scale BV oxidation of cycloalkenones. ${ }^{20}$

Widening the range of substrates: whole cell biotransformations of methyl substituted cycloalkanones $\mathbf{5 a - c}$ and cycloalkenones $\mathbf{5 d} \mathbf{d} \mathbf{g}$ were performed (Scheme 2). All saturated ketones 5a-c were transformed by both enzymes but a strong disparity, depending on substrate and enzyme, was observed in enantio- or enantiotoposelectivity as shown in Tables 2 and 3. The results obtained with $\mathrm{BVMO}_{\text {Ocean }}$ were very close to those reported with the well-known $\mathrm{CHMO}_{\text {Acineto }}$, this was consistent with their high sequence identity (58\%). However, even though they have an equivalent identity (53\%), $\mathrm{BVMO}_{\text {Parvi }}$ and $\mathrm{CPMO}_{\text {Coma }}$ differed in enantioselectivity (see ESI $\dagger$ ).

The most surprising behavior arose from the reactivity of both new enzymes with substituted cycloalkenones. Only BVMO $_{\text {Parvi }}$ was able to transform ketones 5d-f and afford exclusively enollactones 6d-f in good yields (Table 2) as for experiments with 1a-c. Moreover, highly optically active enol-lactone $(R)-\mathbf{6 g}$ was obtained from $5 \mathrm{~g}$ (enantiomeric ratio $E=37$ ), highlighting for the first time the BVMO capacity to catalyze enantioselective enol-lactone formation. On the other hand, $\mathbf{5 g}$ was the unique methylated enone of the series to act as a substrate of $\mathrm{BVMO}_{\text {Ocean, }}$, suggesting a strong sensitivity of the enzyme towards the double bond substitution. $\mathbf{5 g}$ was oxidized into the conjugated enelactone $\mathbf{7 g}$ with the same regioselectivity as the non-substituted enones. A high enantioselectivity was also observed $(E=31)$, 
Table 2 Biotransformations of methylated ketones $\mathbf{5 a - g}$ by $E$. coli $\mathrm{BL21(DE3) \Delta nemA} \mathrm{strain} \mathrm{producing} \mathrm{BVMO} \mathrm{Parvi}$

\begin{tabular}{|c|c|c|c|}
\hline Ketone $^{a}$ & $\begin{array}{l}\text { Residual } 5 \text { yield }{ }^{b}(\%) \\
\text { ee (abs conf) }\end{array}$ & $\begin{array}{l}\text { Lactone } 6 \text { yield }{ }^{b}(\%) \\
\text { ee (abs conf) }\end{array}$ & $\begin{array}{l}\text { Enantiomeric } \\
\text { ratio } E^{c}\end{array}$ \\
\hline \multirow[t]{2}{*}{$5 \mathbf{a}$} & 78 & 21 & \\
\hline & 14 ee $(S)$ & 23 ee $(R)$ & 3 \\
\hline \multirow[t]{2}{*}{$5 b$} & 79 & 20 & \\
\hline & 33 ee $(R)$ & 88 ee $(S)$ & 15 \\
\hline \multirow[t]{2}{*}{$5 c$} & - & 93 & \\
\hline & & 68 ee $(R)$ & - \\
\hline $5 d$ & 0 & 71 & - \\
\hline $5 e$ & 0 & 75 & - \\
\hline $5 f$ & 0 & 70 & - \\
\hline \multirow[t]{2}{*}{$5 \mathrm{~g}$} & 80 & 15 & \\
\hline & 30 ee $(S)$ & 93 ee $(R)$ & 37 \\
\hline
\end{tabular}

${ }^{a}$ Preparative biotransformations were carried out at the $3 \mathrm{mM}$ scale in 2L flasks. ${ }^{b}$ Yields were determined by GC analysis using internal standard. ${ }^{c}$ Enantiomeric ratios were calculated from three couples of substrate and product ees.

Table 3 Biotransformations of methylated ketones $\mathbf{5 a}-\mathbf{c}$ and $\mathbf{5} \mathbf{g}$ by $E$. coli $\mathrm{BL} 21(\mathrm{DE} 3) \Delta$ nemA strain producing $\mathrm{BVMO}_{\text {Ocean }}$

\begin{tabular}{|c|c|c|c|c|}
\hline Ketone $^{a}$ & $\begin{array}{l}\text { Residual } 5 \\
\text { yield }(\%) \\
\text { ee (abs conf) }\end{array}$ & $\begin{array}{l}\text { Lactone } 6 \text { yield }^{b}(\%) \\
\text { ee (abs conf) }\end{array}$ & $\begin{array}{l}\text { Lactone } 7 \text { yield }^{b}(\%) \\
\text { ee (abs conf) }\end{array}$ & $E^{c}$ \\
\hline \multirow[t]{2}{*}{$5 a$} & 70 & 24 & 0 & \\
\hline & 29 ee $(R)$ & 56 ee $(S)$ & - & 5 \\
\hline \multirow[t]{2}{*}{$5 b$} & 0 & 50 & 48 & \\
\hline & - & $>98$ ee $(R)$ & $>98$ ee $(S)$ & - \\
\hline \multirow[t]{2}{*}{$5 c$} & 0 & 92 & 0 & \\
\hline & - & $>98$ ee $(S)$ & - & - \\
\hline \multirow[t]{2}{*}{$5 \mathrm{~g}$} & 60 & 0 & 35 & \\
\hline & 65 ee $(S)$ & - & 88 ee $(R)$ & 31 \\
\hline
\end{tabular}

${ }^{a}$ Preparative biotransformations were carried out at $3 \mathrm{mM}$ scale into $2 \mathrm{~L}$ flasks. ${ }^{b}$ Yields were determined by GC analysis using internal standard. ${ }^{c} E$ : enantiomeric ratio, calculated from three couples of substrate and product ees.

leading to the preferential formation of the $(R)$-enantiomer in good yield (Table 3).

The same experiments were performed with a similarly constructed knock-out E. coli strain producing $\mathrm{CPMO}_{\text {Coma }}$ and revealed a behavior of this enzyme identical to that of $\mathrm{BVMO}_{\text {Parvi }}$ (see Table 4 and ESI $\dagger$ ). This outcome highlighted the advantage of our knock-out $E$. coli strain since in a previous published study based on an unmodified strain, any eventual $\mathrm{BV}$ activity of $\mathrm{CPMO}_{\mathrm{Coma}}$ on cyclohexenones was totally masked by reductase activity. ${ }^{21}$

Table 4 Biotransformations of methylated ketones $\mathbf{5 d - g}$ by $E$. coli

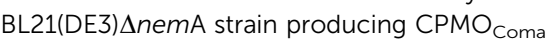

\begin{tabular}{|c|c|c|c|}
\hline Ketone & $\begin{array}{l}\text { Residual } 5 \text { yield }{ }^{a}(\%) \\
\text { ee (abs conf) }\end{array}$ & $\begin{array}{l}\text { Lactone } 6 \text { yield }{ }^{a}(\%) \\
\text { ee (abs conf) }\end{array}$ & $\begin{array}{l}\text { Enantiomeric } \\
\text { ratio } E^{b}\end{array}$ \\
\hline $5 d$ & 0 & 79 & - \\
\hline $5 e$ & 0 & 82 & - \\
\hline $5 f$ & 0 & 85 & - \\
\hline \multirow[t]{2}{*}{$5 \mathrm{~g}$} & 65 & 30 & \\
\hline & 35 ee $(S)$ & 68 ee $(R)$ & 7 \\
\hline
\end{tabular}

${ }^{a}$ Yields were determined by GC analyses using internal standard.

${ }^{b}$ Enantiomeric ratio was calculated from three couples of ees.
In contrast, we confirmed, as previously suggested, ${ }^{11}$ that $\mathrm{CHMO}_{\text {Acineto }}$ was unable to use cyclohexenones as substrates although sharing $58 \%$ sequence identity with $\mathrm{BVMO}_{\text {ocean }}$.

Thus the three enzymes displayed the same enantiopreference but a regiodivergence was observed between $\mathrm{BVMO}_{\text {Ocean }}$ on one hand and $\mathrm{CPMO}_{\text {Coma }}$ and $\mathrm{BVMO}_{\text {Parvi }}$ on the other hand. The protein sequences show a low similarity $(35-40 \%)$ between these two groups, it is likely that their particular activities towards enones come from a very subtle variation in the aminoacid arrangement that will require comparisons with a larger number of enzymes with similar activities before being understood.

In conclusion, a long standing gap in the chemistry of BVMOs has been filled. We confirmed that this family of enzymes is able to convert without exception the same type of compounds as peracids do. The two original activities discovered on cyclic $\alpha, \beta$-unsaturated ketones associated with a strategy based on knockout mutant strains allowed easy access to enol-lactones and conjugated ene-lactones, expanding the toolbox of the synthetic chemist. The range of substrates still remains to be explored more widely and the molecular reasons for the rareness of BVMO mediated reactivity towards enones need to be understood. Nevertheless, these preliminary studies, particularly as far as enantioselectivity is concerned, pave the way toward valuable new enantiopure unsaturated synthons.

This work and T. Reignier PhD fellowships were supported by the French National Research Agency (NaturaDyRe project ANR-10-CD2I-014). We are deeply grateful to Dr E. Bouveret, L. My and Dr P. Moreau for biological materials gift and advice, E. Courvoisier-Dezord and Prof. G. Iacazio for AVB Platform facilities and Prof. J. N. Sturgis for his critical reading.

\section{Notes and references}

1 (a) A. Parenty, X. Moreau, G. Niel and J.-M. Campagne, Chem. Rev., 2013, 113, PR1; (b) B. Nagaiah and A. V. Narsaiah, Helv. Chim. Acta, 2013, 96, 1948; (c) R. S. Ghogare, S. B. Wadavrao and A. V. Narsaiah, Tetrahedron Lett., 2013, 54, 5674; (d) Y. Zhang, J.-S. Wang, D.-D. Wei, Y.-C. Gu, X.-B. Wang and L.-Y. Kong, J. Nat. Prod., 2013, 76, 1191; (e) S.-M. Lee, W.-G. Lee, Y.-C. Kim and H. Ko, Bioorg. Med. Chem. Lett., 2011, 21, 5726; $(f)$ D. K. Reddy, V. Shekhar, P. Prabhakar, B. C. Babu, B. Siddhardha, U. S. N. Murthy and Y. Venkateswarlu, Eur. J. Med. Chem., 2010, 45, 4657; $(g)$ M. Herrera-Ruiz, M. González-Cortazar, E. JiménezFerrer, A. Zamilpa, L. Álvarez, G. Ramírez and J. Tortoriello, J. Nat. Prod., 2006, 69, 59; (h) H. Shigemori, S. Shimamoto, M. Sekiguchi, A. Ohsaki and J. Kobayashi, J. Nat. Prod., 2002, 65, 82; (i) S. V. Ley, L. R. Cox and G. Meek, Chem. Rev., 1996, 96, 423.

2 (a) J. Mo, R. Yang, X. Chen, B. Tiwari and Y. R. Chi, Org. Lett., 2013, 15, 50; (b) R. Larsson, O. Sterner and M. Johansson, Org. Lett., 2009, 11, 657; (c) J. J. Rubal, F. J. Moreno-Dorado, F. M. Guerra, Z. D. Jorge, M. del Carmen Galán, G. M. Salido, S. B. Christensen, H. Søhoel and G. M. Massanet, Planta Med., 2010, 76, 284; (d) M. Jiménez-Tenorio, M. C. Puerta, P. Valerga, F. J. Moreno-Dorado, F. M. Guerra and G. M. Massanet, Chem. Commun., 2001, 2324.

3 (a) B. Mao, M. Fañanás-Mastral and B. L. Feringa, Org. Lett., 2013, 15, 286; (b) A. Yanagisawa, T. Fujinami, Y. Oyokawa, T. Sugita and K. Yoshida, Org. Lett., 2012, 14, 2434; (c) M. E. Muratore, C. A. Holloway, A. W. Pilling, R. I. Storer, G. Trevitt and D. J. Dixon, J. Am. Chem. Soc., 2009, 131, 10796; (d) H. Yanai, A. Takahashi and T. Taguchi, Tetrahedron, 2007, 63, 12149; (e) C. D. Hopkins, L. Guan and H. C. Malinakova, J. Org. Chem., 2005, 70, 6848; $(f)$ K. R. Campos, J. C. S. Woo, S. Lee and R. D. Tillyer, Org. Lett., 2004, 6, 79.

4 K. C. Nicolaou, R. Yu, L. Shi, Q. Cai, M. Lu and P. Heretsch, Org. Lett., 2013, 15, 1994 and references herein.

5 W. Zhao, Z. Li and J. Sun, J. Am. Chem. Soc., 2013, 135, 4680. 
6 (a) Y. Li, Z. Yu and H. Alper, Org. Lett., 2007, 9, 1647; (b) A. T. Davies, J. E. Taylor, J. Douglas, C. J. Collett, L. C. Morrill, C. Fallan, A. M. Z. Slawin, G. Churchill and A. D. Smith, J. Org. Chem., 2013, 78, 9243; (c) X. Hao, X. Liu, W. Li, F. Tan, Y. Chu, X. Zhao, L. Lin and X. Feng, Org. Lett., 2014, 16, 134.

7 A. K. Chatterjee, J. P. Morgan, M. Scholl and R. H. Grubbs, J. Am. Chem. Soc., 2000, 122, 3783.

8 (a) G. R. Krow, Org. React., 1993, 43, 251-798; (b) C. JimenezSanchidrian and J. R. Ruiz, Tetrahedron, 2008, 64, 2011.

9 For recent reviews, see: $(a)$ K. Balke, M. Kadow, H. Mallin, S. Saß and U. T. Bornscheuer, Org. Biomol. Chem., 2012, 10, 6249; (b) H. Leisch, K. Morley and P. C. K. Lau, Chem. Rev., 2011, 111, 4165; (c) V. Alphand and R. Wohlgemuth, Curr. Org. Chem., 2010, 14, 1928; (d) D. E. Torres Pazmiño, H. M. Dudek and M. W. Fraaije, Curr. Opin. Chem. Biol., 2010, 14, 138; (e) G. de Gonzalo, M. D. Mihovilovic and M. W. Fraaije, ChemBioChem, 2010, 11, 2208.

10 (a) B. J. Yachnin, T. Sprules, M. B. McEvoy, P. C. K. Lau and A. M. Berghuis, J. Am. Chem. Soc., 2012, 134, 7788; (b) D. Sheng, D. P. Ballou and V. Massey, Biochemistry, 2001, 40, 11156.

11 For instance, $\mathrm{CHMO}_{\text {Acineto }}$, although known for its outstanding substrate acceptance, did not oxidize cyclohexenones (N. Oberleitner, C. Peters, J. Muschiol, M. Kadow, S. Saß, T. Bayer, P. Schaaf, N. Iqbal, F. Rudroff, M. D. Mihovilovic and U. T. Bornscheuer, ChemCatChem, 2013, 5, 3524).

12 M. T. Bes, R. Villa, S. M. Roberts, P. W. H. Wan and A. Willetts, J. Mol. Catal. B: Enzym., 1996, 1, 127.

13 It was recently assumed that OTEMO, a BVMO from Pseudomonas putida, used a few enones as substrates. Unfortunately, no evidence of unsaturated lactone formation has been provided to date (M. Kadow, K. Loschinski, S. Saß, M. Schmidt and U. T. Bornscheuer, Appl. Microbiol. Biotechnol., 2012, 96, 419).
1428 sequences coding for experimentally confirmed BVMOs were collected and used for similarity sequence analyses using UniprotKB and Genoscope databases. Candidate enzymes were then selected according to their genome availability in the Genoscope strain collection (700 prokaryote species). Around 370 candidate enzymes were selected after clustering and 180 were cloned $(46 \%$ of the selected genes had a GC content $>65 \%$ ). Sixty enzymes were overexpressed in E. coli BL21. The whole screening will be detailed elsewhere.

15 C. Vergne-Vaxelaire, F. Bordier, A. Fossey, M. Besnard-Gonnet, A. Debard, A. Mariage, V. Pellouin, A. Perret, J.-L. Petit, M. Stam, M. Salanoubat, J. Weissenbach, V. de Berardinis and A. Zaparucha, Adv. Synth. Catal., 2013, 355, 1763.

16 In whole-cell processes, cofactor regeneration was provided by the cellular machinery itself and avoided the need for the exogenous NADPH recycling system (I. Hilker, M. C. Gutiérrez, R. Furstoss, J. Ward, R. Wohlgemuth and V. Alphand, Nat. Protoc., 2008, 3, 546).

17 R. E. Williams, D. A. Rathbone, N. S. Scrutton and N. C. Bruce, Appl. Environ. Microbiol., 2004, 70, 3566.

18 T. Baba, T. Ara, M. Hasegawa, Y. Takai, Y. Okumura, M. Baba, K. A. Datsenko, M. Tomita, B. L. Wanner and H. Mori, Mol. Syst. Biol., 2006, 2, 2006.0008.

19 J. H. Miller, A Short Course in Bacterial Genetics, Cold Spring Harbor Laboratory Press, Plainview, NY, 1992.

20 Moreover, the use of these knock-out strains for future targeting enones screenings could enhance the sensitivity of the assays by decreasing the "background activity" due to NADPH consumption by NemA.

21 M. D. Mihovilovic, R. Snajdrova and B. Grötzl, J. Mol. Catal. B: Enzym., 2006, 39, 135. 